\title{
Capitalizing on fine milk composition for breeding and management of dairy cows ${ }^{1}$
}

\author{
N. Gengler, ${ }^{* 2}$ H. Soyeurt, ${ }^{*}$ F. Dehareng,† C. Bastin, ${ }^{*}$ F. Colinet, ${ }^{*}$ H. Hammami, ${ }^{*}$ M.-L. Vanrobays, ${ }^{*}$ A. Lainé, ${ }^{*}$ \\ S. Vanderick, ${ }^{*}$ C. Grelet, $†$ A. Vanlierde, $†$ E. Froidmont, $†$ and P. Dardenne† \\ ${ }^{*}$ Agriculture, Bio-engineering and Chemistry Department, Gembloux Agro-Bio Tech, University of Liège, 5030 Gembloux, Belgium \\ †Walloon Agricultural Research Centre, 5030 Gembloux, Belgium
}

\begin{abstract}
The challenge of managing and breeding dairy cows is permanently adapting to changing production circumstances under socio-economic constraints. If managing and breeding address different timeframes of action, both need relevant phenotypes that allow for precise monitoring of the status of the cows, and their health, behavior, and well-being as well as their environmental impact and the quality of their products (i.e., milk and subsequently dairy products). Milk composition has been identified as an important source of information because it could reflect, at least partially, all these elements. Major conventional milk components such as fat, protein, urea, and lactose contents are routinely predicted by mid-infrared (MIR) spectrometry and have been widely used for these purposes. But, milk composition is much more complex and other nonconventional milk components, potentially predicted by MIR, might be informative. Such new milk-based phenotypes should be considered given that they are cheap, rapidly obtained, usable on a large scale, robust, and reliable. In a first approach, new phenotypes can be predicted from MIR spectra using techniques based on classical prediction equations. This method was used successfully for many novel traits (e.g., fatty acids, lactoferrin, minerals, milk technological properties, citrate) that can be then useful for management and breeding purposes. An innovation was to consider the longitudinal nature of the relationship between the trait of interest and the MIR spectra (e.g., to predict methane from MIR). By avoiding intermediate steps, prediction errors can be minimized when traits of interest (e.g., methane, energy balance, ketosis) are predicted directly from MIR spectra. In a second approach, research is ongoing
\end{abstract}

Received July 20, 2015.

Accepted November 16, 2015.

${ }^{1}$ Presented as part of the Joint Interbull JAM Symposium: Milk Spectral Data - Cost-Effective Information to Improve Expensive and Limited Traits in Dairy Cattle Breeding at the ADSA-ASAS Joint Annual Meeting, Orlando, Florida, July 2015.

${ }^{2}$ Corresponding author: nicolas.gengler@ulg.ac.be to detect and exploit patterns in an innovative manner, by comparing observed with expected MIR spectra directly (e.g., pregnancy). All of these traits can then be used to define best practices, adjust feeding and health management, improve animal welfare, improve milk quality, and mitigate environmental impact. Under the condition that MIR data are available on a large scale, phenotypes for these traits will allow genetic and genomic evaluations. Introduction of novel traits into the breeding objectives will need additional research to clarify socio-economic weights and genetic correlations with other traits of interest.

Key words: dairy cattle, milk mid-infrared, management, breeding

\section{INTRODUCTION}

Management and breeding of dairy cows face the challenge of permanently adapting to changing production circumstances under socio-economic constraints. Previously, Olesen et al. (1999) linked sustainability not only to short- and long-term economic but also to environmental, genetic diversity, ethical, and social aspects. More recently, Boichard and Brochard (2012) also identified new challenges regarding sustainability with its 3 pillars: economic, societal, and environmental. They also supported the idea that relevant phenotypes will be needed to address already existing but also emerging challenges. Even if timeframes of action are different, challenges in management and breeding are similar and the requirement to access novel traits, especially linked to animal functionality, were clearly identified (e.g., Egger-Danner et al., 2015). Negative genetic trends in health and fitness traits have been observed in the last years because of their unfavorable genetic correlations with milk yield, the major trait of interest. To support the sustainability of dairy cattle production in the future, such unfavorable trends have to be compensated. Herd management, but also breeding, may have the potential to counterbalance for these effects to favor fertility, udder health, and metabolic diseases against increased production and therefore 
these actions could increase profit without compromising welfare. Unfortunately, access to direct (i.e., cow heath) data is still a challenge, especially if large-scale and extensive comparable data across different herds are needed as, for instance, for breeding and benchmarking purposes. Similarly, management and selection for product quality (i.e., milk and subsequently dairy products) require access to high-throughput data given that alternative reference laboratory techniques (e.g., gas chromatography for fatty acid profiling) are out of question. Similarly opportunities to record direct behavioral and environmental impact traits are very limited, especially when we consider recording on a very large scale.

Standard milk components such as fat, protein, urea, and lactose contents, except SCC, are obtained using a technology called mid-infrared (MIR) spectroscopy (e.g., Biggs, 1978). Because the quantification of components is done using chemometric methods, the word spectrometry is also commonly used. As reported recently by De Marchi et al. (2014), this technology, which is installed in almost every milk analyses laboratory around the world, could also be used to determine fine milk composition. But this is not the final stage of development of this technology, as several innovations were recently described allowing its rise above an alternative method to detect chemical composition. The goal of this paper, inside the general symposium "Milk spectral data-Cost-effective information to improve expensive and limited traits in dairy cattle breeding," is to describe the latest developments and state of the art on the way that dairy cow management and breeding can benefit from milk composition assessed through MIR spectral data. This includes recent methodological innovations and developments to improve the use of fine milk composition, assessed through MIR spectral technology. Interactions between these innovations and the use of milk composition for breeding and management of dairy cows are described. Finally, recent innovations in the direct use of milk MIR spectral data are described.

\section{USEFULNESS OF (FINE) MILK COMPOSITION}

Not only is milk composition affected by the genetic background of cows (e.g., breed), but also the diet they are fed, their health, and numerous other effects. Changes in milk composition can also be used for precise monitoring of the status and health of the cows, and therefore their wellbeing, their diet, their environmental impact, and obviously the composition and the quality of their products (i.e., milk and subsequently dairy products). Milk composition traits play the role of indicator traits replacing a difficult to observe trait by a different, but reasonably highly correlated trait. An example is SCC, which was developed as an indicator of udder health (e.g., Schukken et al., 2003). The concept of a biomarker is defined as "a characteristic that is objectively measured and evaluated as an indicator of normal biologic processes, pathogenic processes, or ... responses to an ... intervention" (e.g., National Institutes of Health, 2001). The extension of the concept of biomarkers to different milk components, which then play the role of milk biomarkers, has been rather well described in literature (e.g., Bjerre-Harpøth et al., 2012).

\section{Assessing Animal Health and Status}

Due to the very intensive interaction between blood circulation and milk production (Bramley et al., 1992), milk composition is well recognized as a very easily accessible source of information on the (subclinical) changes in the health status of dairy cows (e.g., Hamann and Krömker, 1997). Mulligan et al. (2006) summarized that several milk components could be used in the detection of metabolic disorders (e.g., induced by an unbalanced diet). Major conventional milk components that have been available for a long time, such as fat, protein, and potentially urea and lactose, were considered by many researchers as potential tools and proxies to assess the changes in the status of the cows. Several examples were reported in literature. Plaizier et al. (2008) linked milk fat depression to potential SARA. Also, a high fat to protein ratio was suggested as an indicator for cows with a high risk of negative energy balance leading to related afflictions such as ketosis, displaced abomasum, ovarian cyst, lameness, mastitis, and body condition loss (Friggens et al., 2007). Frank and Swensson (2002) suggested that urea content, together with the protein content of the milk, could indicate the balance between protein and energy in the rumen. They also established that the efficiency of nitrogen utilization and the ammonia emission reduction could be optimized using the knowledge of urea and protein content. Brandt et al. (2010) summarized literature on the expected effects of mastitis on milk composition, including lactose. In a review, Arnould et al. (2013) summarized several scientific publications showing the benefit and the potential use of these traditional component, but also the use of novel milk composition traits such as fatty acids, BHB, lactoferrin, and others. Examples are the use of BHB in milk as a potential indicator of ketosis (Jorritsma et al., 1998) and lactoferrin (Kawai et al., 1999) as an indicator of mastitis. As reported by De Marchi et al. (2014) in their review, several studies associated body energy status, ketosis, and milk composition. Some authors stressed that cows with severe postpartum negative 
energy balance are more likely to develop metabolic disorders, including ketosis (e.g., Collard et al., 2000). Clinical and potentially subclinical ketosis might be rather linked to milk components such as acetone and BHB contents (van Knegsel et al., 2007) than to fat-toprotein ratio (van Knegsel et al., 2010). Van Haelst et al. (2008) extended the list of ketosis-related biomarkers to C18:1 cis-9.

Milk composition is also at the frontier of animal health, wellbeing, and even behavior as individual changes in milk composition at a given moment can be linked not only to changes in the health status but also to the general wellbeing and even to the behavior (e.g., feed intake) of the animals. Interactions between these elements are also linked to management and production systems (e.g., Dechow et al., 2011). Recently, Hammami et al. (2015) reported that differentiated response of milk components to heat stress could be an indicator of the equilibrium between feed intake and reserve mobilization under warm conditions. These authors found that the MIR-predicted content of C18:1 cis-9 in milk could be a very affordable milk biomarker if available. This finding follows results reported by others that this fatty acid reflects body reserve mobilization and thereby fertility (e.g., Bastin et al., 2012).

\section{Assessing Quality of Milk and Milk Products}

Milk is a complex substance (e.g., Jensen, 1995), which reflects its nutritional content and its market value. Milk fat and protein content are used to determine the value of raw milk in almost all pricing schemes. Nonstandard components (e.g., solids, lactose, saturated fatty acids) begin to be added in some countries to milk pricing schemes. If some of these components are already available (e.g., lactose), others need an adapted technology to be obtained in routine (e.g., fatty acid profiles). De Marchi et al. (2014) summarized that interest in fatty acids can be explained by their importance as milk quality and nutritional value traits but also due to their influence on other important attributes of milk, especially technological property traits of milk and milk products (e.g., spreadability of butter). Similarly, the characteristics of milk related to cheese making are becoming more important with increasing volume of milk destined for cheese manufacturing. As reported by De Marchi et al. (2014), milk coagulation properties, acidity, and protein composition are important factors in cheese production. Until recently, the available technology did not allow obtaining these traits easily, using cheap routine methods. Because of their link to some technological aspects (e.g., coagulation properties), environmental aspects (e.g., excretion of phosphorus), and animal health (e.g., milk fever or mastitis), and because of their key role for human health, the quantification of mineral contents in milk is also highly desirable.

\section{Assessing Emissions and Interactions with the Environment}

Milk-producing cows interact with their environment. Animals are affected directly but also indirectly by environmental conditions (i.e., extreme weather events). They also release emissions directly or indirectly through their manure or urine into the atmosphere. Currently, nitrogen efficiency and methane production (i.e., feed energy efficiency) are considered as the most important issues, but novel ones are emerging such as phosphorus efficiency. First, ruminants do not efficiently use dietary nitrogen, leading to excess nitrogen excreted in urine and feces. Urea in milk can also be considered as a loss for the value chain. Dairy cows on average secrete in milk 25 to $35 \%$ of their consumed nitrogen, whereas almost all the remaining nitrogen is excreted in urine and feces with about half of the nitrogen excreted in urine (e.g., Castillo et al., 2000). Ishler (2004) reported a range of approximately 60 to $80 \%$ of the nitrogen in urine being in the form of urea. Frank and Swensson (2002) suggested that the efficiency of nitrogen utilization and the ammonia emission reduction could be optimized using milk composition (i.e., urea and protein content). Nitrogen partitioning in the milk could be assessed by separating true protein and nonprotein nitrogen including urea. A second major issue of great concern is the existence of $\mathrm{CH}_{4}$ emissions in dairy cows also contributing to greenhouse gases. These emissions contribute to the carbon footprint of dairy products, but also represent a loss of use of gross energy intake (Johnson and Johnson, 1995) and are closely linked to feed energy efficiency. Most of the $\mathrm{CH}_{4}$ emitted by cattle is eructed. Direct quantification of $\mathrm{CH}_{4}$ is expensive and would not allow measurements on a wide range of animals. Therefore, development of simple methods to obtain indicators of $\mathrm{CH}_{4}$ production is needed. If links with milk composition are obvious for nitrogen, they may be less obvious for $\mathrm{CH}_{4}$. Vlaeminck et al. (2006) reported links between acetate, butyrate, and propionate and several milk fatty acids, all 3 VFA being related to the production of methane. De novo synthesis of milk fatty acids in the mammary gland is dependent on the products of ruminal fermentation (Chilliard et al., 2000) as is the production of eructed $\mathrm{CH}_{4}$ (Dijkstra et al., 2011). Unfortunately recent research on the link of milk fatty acids and $\mathrm{CH}_{4}$ gave inconsistent results, some researchers finding a link between some fatty acids and $\mathrm{CH}_{4}$ (e.g., Dijkstra et al., 2011), but others concluded that milk fatty acids 
alone may not be suitable for developing universal $\mathrm{CH}_{4}$ prediction equations (e.g., Mohammed et al., 2011). Moreover, even the different studies confirming these links did not report similar equations using the same fatty acids (e.g., Dijkstra et al., 2011; Montoya et al., 2011), a major hypothesis being explored is that the fatty acid profile in milk and therefore the proportions of fatty acids relevant to predict $\mathrm{CH}_{4}$ are also influenced by other factors. The influence of feeding practices is well documented (e.g., Mohammed et al., 2011), but this is difficult to assess in field conditions. However, other systematic factors can be described. In particular, lactation stage and heat stress were recently studied, and both seem to influence the equilibrium between feed intake and body reserve mobilization. The later hypothesis was first reported in the context of the interaction between dairy cows and climate by Gengler (2014).

To sum up, literature has shown that many elements in (fine) milk composition are of major interest for management and breeding of dairy cattle. The major issue with these novel fine milk composition traits is that their routine use is compromised without largescale and cheap phenotyping tools as the direct analysis of milk required generally expensive reference methods. Starting with fatty acid composition (Soyeurt et al., 2006), this need for a fast, cheap, and high-throughput method for the determination of (fine) composition in milk was addressed with novel applications of an already existing and routinely used technology, infrared (IR) spectroscopy (De Marchi et al., 2014).

\section{MIR SPECTROMETRY}

The most generalist definition of spectroscopy is the study of the interaction between matter and electromagnetic radiation. Different types of interactions allow a classification of spectral methods. Most important types of interaction are absorption, emission, and reflection. The history of spectroscopy is linked to the analysis of scattered light through a prism as experienced by Isaac Newton, but also to astronomy where the measured spectra are used to determine the chemical composition of far stars. Spectroscopy moved from qualitative (e.g., presence of an element in a star) to quantitative (e.g., chemical composition of liquids such as wine and milk, of solids such as meat, of gases in the air; quality of agricultural products as energy and protein contents of feed stuff, cheese curd firmness) through the development of adapted technological advances such as the interferometer and associated methods. Based on this, Fourier transform spectroscopy was developed. Fourier transform spectroscopy uses different beams containing combinations of many different wavelengths of electromagnetic radiations at once, measuring the total beam intensity. Posteriorly, data are then processed using an algorithm called the Fourier transform to generate the whole spectra (Bertrand and Baeten, 2006).

Spectroscopy can also be associated with the detections of atoms or molecules. For atoms, the absorptions or emissions show spectral lines associated with electronic transmissions between electron orbits. For molecules different types of interaction exist. For the type of spectrometry used to detect the (fine) composition of milk, molecular vibrations (mainly stretching and bending) linked to specific molecular bonds are used, as vibrational transitions typically require an amount of energy that corresponds to a specific IR region of the electromagnetic spectrum (Lachenal, 2006).

Milk analysis uses absorption IR spectroscopy associated with the near-IR region $(800-2,500 \mathrm{~nm}$ or 4,000-12,500 $\mathrm{cm}^{-1}$ ) but more often the MIR region $\left(2,500-25,000 \mathrm{~nm}\right.$ or $\left.400-4,000 \mathrm{~cm}^{-1}\right)$. Currently all standard and conventional milk component quantification used for breeding and management, except SCC, are based on MIR spectroscopy. Grelet et al. (2015) reported more details about the history of the use of MIR for milk composition analysis. In traditional absorption spectrometry, transmittance (T) or absorbance (A), a reciprocal logarithmic function of transmittance $\mathrm{A}=-\log _{10}(\mathrm{~T})$, are considered (Meurens, 2006). Measurements are taken at up to thousand different wavenumbers (e.g., 899 for Bentley, 935 for Delta, and 1,060 for Foss instruments) which are an inverted function of wavelengths and expressed in centimeters ${ }^{-1}$. The absorbance values along this range of wavenumbers form what is generally called a MIR spectrum. Observations in a given spectrum are then combined in a linear equation to predict the concentration of the milk component of interest. This is an extension of the Beer-Lambert law linking absorbance to concentration. The process of deriving and validating the prediction equation needed in spectrometry is called calibration. It involves obtaining values from reference analysis also often called gold-standard values, covering the expected variability of the component and the corresponding spectral data. In parallel, spectral data also need to cover the expected spectral variability from commercial farms to be used when predicting the component. This can be a major issue when an equation developed in one environment is transferred to another environment. The spectral variability in the new environment has to be checked to remain compatible with the variability of the reference data. The concept of the global standardized Mahalanobis distance $\mathrm{H}$ value as defined by Shenk and Westerhaus (1991) is often used. Also, predictions 
have to be checked carefully for outliers. Gold-standard analysis results for detected outliers can be valuable additions to the reference data sets.

Prediction equations developed for one spectrometer cannot necessarily be trusted on another apparatus even if it is the same model. As reported by Soyeurt et al. (2011), the repeatability of the results can be improved by considering the repeatability across instruments through the use of MIR spectra for the same samples but generated on different instruments. Some calibration procedures and software specifically use this information as stored in a file called a repeatability file.

Data points in spectral data are highly correlated and prediction equations potentially over-parameterized. Therefore, the use of adapted statistical tools to derive prediction equation coefficient is required (Vigneau et al., 2006). Commonly used are multivariate methods such as partial least squares to derive the coefficients needed for the prediction equation. De Marchi et al. (2014) gave an overview of often used pretreatments of spectral data applied before calibrations.

\section{PHENOTYPES BASED ON MIR SPECTROMETRY AND NOVEL MILK COMPOSITION}

The number of studies investigating the effectiveness of MIR spectrometry to predict novel phenotypes for dairy applications has strongly increased since the mid2000s (De Marchi et al., 2014), highlighting a growing interest in the topic. These studies include the development of direct quantification of traits (phenotypes) of interest (e.g., fatty acids as reported by Soyeurt et al., 2006) but also of indirect, correlated, indicator traits (e.g., lactoferrin indicator as reported by Soyeurt et al., 2007). As already explained earlier, many (fine) milk components are considered as relevant phenotypes (i.e., biomarkers) or are linked to phenotypes that allow for precise monitoring of the status of the cows, their products (i.e., milk and subsequently dairy products), their behavior and wellbeing, and their environmental impact. Several European projects have addressed this topic from different points of view including RobustMilk (fatty acids and lactoferrin predictions), GreenHouseMilk (methane predictions), OptiMIR (mostly MIR tool implementation technology and novel management use, see Friedrichs et al., 2015), and GplusE (mostly health traits).

Novel milk phenotypes should add relevant information to existing phenotypes either because they are providing new information in comparison to existing phenotypes (i.e., on the technological properties of milk) or because they supplement existing phenotypes (i.e., lactoferrin content in milk would supplement SCS as an indicator of clinical mastitis, Soyeurt et al., 2011).
Hence, the large screening of these novel traits in routine should be complementary to the potentially limited recording of existing direct traits. Novel phenotypes should be highly correlated with values obtained using the gold standard method, and not necessarily replace the gold standard. This is different from its classical use in chemistry where the objective of MIR spectrometry is to replace the (gold) standard method, becoming itself the reference method. In animal production, the objective is to develop a prediction (i.e., indicator) that can be used in routine on a large scale toward a specific objective (e.g., an indicator of energy balance to select for fertility) and that is cheap, reliable, and robust but still achieves the best possible accuracy of prediction. As explained by De Marchi et al. (2014), MIR spectrometry was used successfully in animal production for many novel traits (e.g., fatty acids, lactoferrin, minerals, milk technological properties), with new traits being still added (e.g., citrate, Bastin et al., 2015) that can then be useful for management and breeding purposes. For management, by using predictions for a group of animals (e.g., herd), under the hypothesis that prediction errors are random, accuracy of predictions for the group will increase. Similarly, random noise of prediction will affect the heritability of the predictions, but this should normally not hinder their use for breeding purposes. Moreover, in animal breeding, correlated traits are often successfully used that show only moderate genetic correlations (e.g., 0.5-0.7) with the traits of interest. In terms of coefficient of determination, a parameter that is often used by chemiometrists to assess the quality of prediction, an $\mathrm{R}^{2}$ of 0.5 would be considered very low and many MIR predictions are well above this value (De Marchi et al., 2014). Still, potential users should never forget that they are using indicator traits and not the gold-standard traits and that the genetic correlations between these traits could be very different from the phenotypic correlations approximated as the square root of the coefficients of determination.

\section{RECENT INNOVATIONS IN THE USE OF MILK MIR SPECTRAL DATA FOR MANAGEMENT AND BREEDING}

Given the novel usage of milk MIR spectral data in animal production, several methodological aspects have the potential to broaden the way the data are used beyond the use of a direct prediction equation of traits of interest. A major issue that was already recognized is that the relationship between the trait to predict and the variables used (e.g., milk components) can be influenced by other factors. This would lead to nonconstant prediction coefficient. A good illustration is recent and ongoing research on the link between $\mathrm{CH}_{4}$ 
and milk composition. Given that fatty acid profiles in milk are highly influenced by lipomobilization (e.g., Van Haelst et al., 2008), it is rather unlikely that the link between methane and fatty acids is constant. This was confirmed by recent research (Vanrobays et al., 2015) and applied by Vanlierde et al. (2015).

A second innovation was to link directly MIR spectra to complex phenotypes or phenotypes that are not directly related to a milk component. Recent examples are studies by McParland et al. (2011, 2014) linking energy balance, body energy status, and related traits directly to MIR spectra. By avoiding intermediate steps, prediction errors can theoretically be minimized when traits of interest are predicted directly from MIR spectra and not from milk components that are themselves predicted by MIR. In recent research on the prediction of $\mathrm{CH}_{4}$, both innovations (e.g., lactation-stagespecific coefficients and direct use of MIR spectra) were combined (Vanlierde et al., 2015). Ongoing research exploits at different places similar strategies to predict SARA or (subclinical) ketosis (Friedrichs et al., 2015). Especially for ketosis, the relationship between milk composition and the ketotic status of the cow can be considered largely nonlinear (i.e., a link can be establish to key milk components such as acetone, BHB, and citrate when they go over certain thresholds), thereby complicating any attempt to use spectral data directly. Instead, simplified decision trees (e.g., Grzesiak and Zaborski, 2012) are currently proposed based on MIR predictions of key milk components. Some recent developments were described by Davière (2014), Commun and Pezon (2015), and Schwarz et al. (2015).

It is likely that most value, especially for management, lies in the modeling of milk components, addressing their longitudinal nature, and the comparison of expected and observed values. For milk yield and standard components, different studies explored this idea, some using very advanced methods (e.g., Van Bebber et al., 1999), others based on more standard linear mixed models (e.g., Mayeres et al., 2004; Koivula et al., 2007; Bastin et al., 2009). Especially inside the OptiMIR project, which developed management tools based on the direct use of MIR spectra. Research was initiated to detect patterns by comparing observed with expected MIR spectra and to use this information directly (e.g., Lainé et al., 2013, 2015).

Since the early use of MIR spectral techniques, different studies showed (e.g., Biggs, 1978) inherent issues in the stability of predictions between apparatuses and over time. As already explained before, limited means are available to render the predictions more stable across known instruments (e.g., repeatability file). For standard components, such as fat or protein, regular checks are organized with reference samples allowing bias and slope postprediction corrections. This is, however, only possible with classical component predictions where gold-standard values for reference samples are known. As soon as predictions for physiological status, energy balance, $\mathrm{CH}_{4}$, or similar traits are made, postprediction adjustments can no longer be used. In the frame of the OptiMIR project, this issue was recognized and a strategy developed to do pre-prediction standardization of MIR apparatuses. Grelet et al. (2015) describes the deployed technology in detail. The used strategy included a harmonization across different brands, also solving the issue of the portability of prediction equations across brands.

All these novel traits can then be used to define best practices, adjust feeding and health management, improve animal welfare, improve milk quality and limit environmental impact. Under the condition that MIR data are available on a large scale, phenotypes for these traits will allow genetic and genomic evaluations. First, novel traits can be used in a similar fashion as traditional traits (e.g., Gengler et al., 2012; Coffey et al., 2013) using adapted genetic and genomic evaluation systems. Introduction of novel traits into the breeding objectives, or of indicator traits in selection indexes, will need additional research to clarify socio-economic weights and genetic correlation with other traits of interest. Special care has to be taken to avoid unwanted correlated responses. Restricted selection index, as already proposed by Kempthorne and Nordskog (1959) and which allows restriction of correlated responses, may become again very useful as suggested by Gengler et al. (2012).

Given the fact that MIR spectral data provide a fingerprint of the whole milk composition phenotype, this type of data can be associated with the concept of phenomics. Houle et al. (2010) argued that phenomics should be recognized and pursued as an independent discipline to enable the development and adoption of high-throughput and high-dimensional phenotyping. Without any doubt, using MIR spectral data is the method of choice for obtaining high-throughput and high-dimensional phenotyping of milk composition. By acquiring the capacity to characterize the "phenome" milk, the relationship between phenome and genome should allow novel insight into the links between genes and milk composition. Combining multivariate phenotypic (i.e., MIR spectra) and genomic data (i.e., SNP markers) will give new challenges, potentially requiring novel strategies such as feature selection techniques (Saeys et al., 2007). Currently, research has not yet reached this level, but several studies already assessed the genetic content in each data point (wavenumber) estimating heritability along the whole spectrum (Soyeurt et al., 2010; Bittante and Cecchinato, 2013; Dagnachew 
et al., 2013). Especially Dagnachew et al. (2013) developed and tested the idea of direct prediction where the estimated breeding values of the MIR spectral data traits combine into milk component breeding values.

\section{CONCLUSIONS}

This review showed that the use of fine milk composition for breeding and management is warranted under the hypothesis that relevant phenotypes are available to allow precise monitoring of the status of the cows, their health, behavior, and wellbeing as well as their environmental impact and their products (i.e., milk and subsequently dairy products). Conventional milk components such as fat, protein, urea, and lactose contents in milk are currently used but milk composition is much more complex and other components can be used in an informative way. Major conventional milk components are routinely predicted by MIR spectrometry, and research showed that many other novel phenotypes can be predicted using classical MIR-prediction-equationbased techniques. This method was used successfully for many novel traits, obtaining for some precise estimation of contents allowing the replacement of goldstandard methods (e.g., several fatty acids) or for other indicator traits that still are useful for breeding and herd management (e.g., minerals, lactoferrin). Recent research projects supported the development of several technological advances in the use and deployment of MIR technologies. In particular, novel traits might not allow deploying postprediction corrections for bias and slope as currently done in conventional traits, the preprediction standardization of MIR apparatuses will be required. But the development of innovative methodologies to use MIR data is ongoing. An innovation was to consider the longitudinal nature of the relationship between the trait of interest and the MIR spectra (e.g., to predict $\mathrm{CH}_{4}$ from MIR). By avoiding intermediate steps, prediction errors can be minimized when the traits of interest (e.g., $\mathrm{CH}_{4}$, energy balance, ketosis) are predicted directly from MIR spectra. Also, MIR spectra may contain more patterns; therefore, research is ongoing to compare observed from expected MIR spectra directly using the difference to detect the hidden status of the animal (e.g., pregnancy). All of these traits can then be used to define best practices, adjust feeding and health management, improve animal welfare, improve milk quality, and mitigate environmental impact. Under the condition that MIR data are available on a large scale, phenotypes for these traits will allow genetic and genomic evaluations. More advanced genomic and data analysis tools can potentially be used to link the global milk phenome with the genome. However, even after making breeding values for novel traits available, the introduction of novel traits into the breeding objectives will need additional research to clarify socio-economic weights and genetic correlations with other traits of interest. Additional research will also be necessary to access the optimal combination between the collection and use of direct novel traits using reference methods versus the use of MIR predictions or indicator traits in the context of a comprehensive breeding program. A first element to be considered could be the distinction between a breeding objective trait (i.e., the direct trait) and an index trait (i.e., the predictor trait).

\section{ACKNOWLEDGMENTS}

Nicolas Gengler, as a former senior research associate, acknowledges the support of the National Fund for Scientific Research (Brussels, Belgium). The authors gratefully thank the other partners of the Walloon FUTUROSPECTRE agreement: the Walloon Breeding Association (Ciney, Belgium) for providing access to data related to the Walloon milk recording and the milk laboratory Comité du Lait (Battice, Belgium) for providing spectral data. The authors thank the INTERREG IVB NWE program and the Ministry of Agriculture of Walloon Region of Belgium (Service Public de Wallonie, Direction générale opérationnelle "Agriculture, Ressources naturelles et Environnement" DGARNE) for their financial support of the OptiMIR project. The authors also acknowledge the support of the European Commission under the Seventh Framework Program for the RobustMilk, GreenhouseMilk, and GplusE projects, grant agreements FP7KBBE-211708, FP7-PEOPLE-ITN-2008-238562, and FP7-KBBE-613689. The content of the paper reflects only the view of the authors; the community is not liable for any use that may be made of the information contained in this publication. Finally, the authors are grateful to the University of Liege (Service Général d'Informatique, Liege, Belgium) for the use of their Numerically Intensive Computing 3 supercomputer.

\section{REFERENCES}

Arnould, V., R. Reding, J. Bormann, N. Gengler, and H. Soyeurt. 2013. Review: Milk composition as management tool of sustainability. Biotechnol. Agron. Soc. Environ. 17:613-621.

Bastin, C., D. P. Berry, H. Soyeurt, and N. Gengler. 2012. Genetic correlations of days open with production traits and contents in milk of major fatty acids predicted by mid-infrared spectrometry. J. Dairy Sci. 95:6113-6121. http://dx.doi.org/10.3168/jds.2012-5361.

Bastin, C., C. Grelet, M. Gelé, J.-B. Davière, R. Reding, A. Werner, C. Darimont, F. Dehareng, N. Gengler, and P. Dardenne. 2015. Mid-infrared prediction of $\beta$-hydroxybutyrate, acetone and citrate contents in milk. In Final OptiMIR Scientific and Expert Meeting: From Milk Analysis to Advisory Tools (Palais des Congres, Namur, Belgium, April 16-17, 2015). Biotechnol. Agron. Soc. Environ. 19:97-124. 
Bastin, C., L. Laloux, A. Gillon, F. Miglior, H. Soyeurt, H. Hammami, C. Bertozzi, and N. Gengler. 2009. Modeling milk urea of Walloon dairy cows in management perspectives. J. Dairy Sci. 92:35293540. http://dx.doi.org/10.3168/jds.2008-1904.

Bertrand, D., and V. Baeten. 2006. Instrumentation. Pages 247-305 in La spectroscopie infrarouge et ses applications analytiques. 2nd ed. D. Bertrand and E. Dufour, ed. Editions TEC \& DOC, Paris, France.

Biggs, D. A. 1978. Instrumental infrared estimation of fat, protein, and lactose in milk: Collaborative study. J. Assoc. Off. Anal. Chem. 61:1015-1034.

Bittante, G., and A. Cecchinato. 2013. Genetic analysis of the Fouriertransform infrared spectra of bovine milk with emphasis on individual wavelengths related to specific chemical bonds. J. Dairy Sci. 96:5991-6006. http://dx.doi.org/10.3168/jds.2013-6583.

Bjerre-Harpøth, V., N. C. Friggens, V. M. Thorup, T. Larsen, B. M. Damgaard, K. L. Ingvartsen, and K. M. Moyes. 2012. Metabolic and production profiles of dairy cows in response to decreased nutrient density to increase physiological imbalance at different stages of lactation. J. Dairy Sci. 95:2362-2380. http://dx.doi. org/10.3168/jds.2011-4419.

Boichard, D., and M. Brochard. 2012. New phenotypes for new breeding goals in dairy cattle. Animal 6:544-550. http://dx.doi. org $/ 10.1017 /$ S1751731112000018.

Bramley, A. J., F. H. Dodd, G. A. Mein, and J. A. Bramley. 1992. Machine Milking and Lactation. Insight Books, Newbury, UK.

Brandt, M., A. Haeussermann, and E. Hartung. 2010. Invited review: Technical solutions for analysis of milk constituents and abnormal milk. J. Dairy Sci. 93:427-436. http://dx.doi.org/10.3168/ jds.2009-2565.

Castillo, A. R., E. Kebreab, D. E. Beever, and J. France. 2000. A review of efficiency of nitrogen utilisation in lactating dairy cows and its relationship with environmental pollution. J. Anim. Feed Sci. 9:1-32.

Chilliard, Y., A. Ferlay, R. M. Mansbridge, and M. Doreau. 2000. Ruminant milk fat plasticity: Nutritional control of saturated, polyunsaturated, trans and conjugated fatty acids. Ann. Zootech. 49:181-205. http://dx.doi.org/10.1051/animres:2000117.

Coffey, M. P., S. McParland, C. Bastin, E. Wall, D. Berry, and R. F. Veerkamp. 2013. Implementation in breeding programmes. Adv. Anim. Biosci. 4:626-630. http://dx.doi.org/10.1017/ S2040470013000198.

Collard, B. L., P. J. Boettcher, J. C. M. Dekkers, D. Petitclerc, and L. R. Schaeffer. 2000. Relationships between energy balance and health traits of dairy cattle in early lactation. J. Dairy Sci. 83:2683-2690.

Commun, L., and J. Pezon. 2015. La cétose subclinique détectée par le spectre MIR. Elev. Lait 234:48-51.

Dagnachew, B. S., T. H. E. Meuwissen, and T. Ådnøy. 2013. Genetic components of milk Fourier-transform infrared spectra used to predict breeding values for milk composition and quality traits in dairy goats. J. Dairy Sci. 96:5933-5942. http://dx.doi. org/10.3168/jds.2012-6068.

Davière, J.-B. 2014. Detection of ketosis in dairy cattle by determining infrared milk ketone bodies in milk. In 39th Int. Committee for Animal Recording (ICAR) Session, Berlin, Germany. ICAR, Rome, Italy. Accessed Dec. 17, 2015. http://www.icar.org/index. $\mathrm{php} /$ icar-meetings-news/berlin/.

De Marchi, M., V. Toffanin, M. Cassandro, and M. Penasa. 2014. Invited review: Mid-infrared spectroscopy as phenotyping tool for milk traits. J. Dairy Sci. 97:1171-1186. http://dx.doi.org/10.3168/ jds.2013-6799.

Dechow, C. D., E. A. Smith, and R. C. Goodling. 2011. The effect of management system on mortality and other welfare indicators in Pennsylvania dairy herds. Anim. Welf. 20:145-158.

Dijkstra, J., S. M. van Zijderveld, J. A. Apajalahti, A. Bannink, W. J. J. Gerrits, J. R. Newbold, H. B. Perdok, and H. Berends. 2011. Relationships between methane production and milk fatty acid profiles in dairy cattle. Anim. Feed Sci. Technol. 166-167:590-595. http://dx.doi.org/10.1016/j.anifeedsci.2011.04.042.
Egger-Danner, C., J. B. Cole, J. E. Pryce, N. Gengler, B. Heringstad, A. Bradley, and K. F. Stock. 2015. Invited review: Overview of new traits and phenotyping strategies in dairy cattle with a focus on functional traits. Animal 9:191-207. http://dx.doi.org/10.1017/ S1751731114002614

Frank, B., and C. Swensson. 2002. Relationship between content of crude protein in rations for dairy cows and milk yield, concentration of urea in milk and ammonia emissions. J. Dairy Sci. 85:18291838.

Friedrichs, P., C. Bastin, F. Dehareng, B. Wickham, and X. Massart. 2015. OptiMIR - A project aiming the development of novel mid-infrared based management tools for dairy herds. In Final OptiMIR Scientific and Expert Meeting: From milk analysis to advisory tools (Palais des Congrès, Namur, Belgium, April 16-17, 2015). Biotechnol. Agron. Soc. Environ. 19:97-124.

Friggens, N. C., C. Ridder, and P. Løvendahl. 2007. On the use of milk composition measures to predict the energy balance of dairy cows. J. Dairy Sci. 90:5453-5467. http://dx.doi.org/http://dx.doi. org $/ 10.3168 /$ jds.2006-821.

Gengler, N. 2014. Mitigation strategies versus adaptation strategies. In Animal Selection, Genetics and Genomics Network Workshop, Aug. 17, 2015, Vancouver, BC, Canada. Accessed Dec. 17, 2015. http://orbi.ulg.ac.be/bitstream/2268/171555/1/NGENGLER_ VF.pdf.

Gengler, N., T. Troch, S. Vanderick, C. Bastin, and H. Soyeurt. 2012. Implementing a national routine genetic evaluation for milk fat compositions as first step towards genomic predictions. Interbull Bull. 46:80-84.

Grelet, C., J. A. Fernández Pierna, P. Dardenne, V. Baeten, and F. Dehareng. 2015. Standardization of milk mid-infrared spectra from a European dairy network. J. Dairy Sci. 98:2150-2160. http:// dx.doi.org/10.3168/jds.2014-8764.

Grzesiak, W., and D. Zaborski. 2012. Examples of the use of data mining methods in animal breeding. Pages $303-324$ in Data Mining Applications in Engineering and Medicine. A. Karahoca, ed. InTech, Rijeka, Croatia.

Hamann, J., and V. Krömker. 1997. Potential of specific milk composition variables for cow health management. Livest. Prod. Sci. 48:201-208. http://dx.doi.org/10.1016/S0301-6226(97)00027-4.

Hammami, H., J. Vandenplas, M.-L. Vanrobays, B. Rekik, C. Bastin, and N. Gengler. 2015. Genetic analysis of heat stress effects on yield traits, udder health, and fatty acids of Walloon Holstein cows. J. Dairy Sci. 98:4956-4968. http://dx.doi.org/10.3168/ jds.2014-9148.

Houle, D., D. R. Govindaraju, and S. Omholt. 2010. Phenomics: The next challenge. Nat. Rev. Genet. 11:855-866. http://dx.doi. org/10.1038/nrg2897.

Ishler, V. 2004. Nitrogen, ammonia emissions and the dairy cow. Ext. Assoc. Pa. State Univ. Atl. CSREES Reg. Water Qual. Proj.

Jensen, R. G. 1995. Handbook of Milk Composition. Academic Press, Waltham, MA.

Johnson, K. A., and D. E. Johnson. 1995. Methane emissions from cattle. J. Anim. Sci. 73:2483-2492.

Jorritsma, R., S. J. C. Baldeé, Y. H. Schukken, T. Wensing, and G. H. Wentink. 1998. Evaluation of a milk test for detection of subclinical ketosis. Vet. Q. 20:108-110. http://dx.doi.org/10.1080 /01652176.1998.9694851.

Kawai, K., S. Hagiwara, A. Anri, and H. Nagahata. 1999. Lactoferrin concentration in milk of bovine clinical mastitis. Vet. Res. Commun. 23:391-398.

Kempthorne, O., and A. W. Nordskog. 1959. Restricted selection indices. Biometrics 15:10. http://dx.doi.org/10.2307/2527598.

Koivula, M., J. I. Nousiainen, J. Nousiainen, and E. A. Mäntysaari. 2007. Use of herd solutions from a random regression testday model for diagnostic dairy herd management. J. Dairy Sci. 90:2563-2568. http://dx.doi.org/10.3168/jds.2006-517.

Lachenal, G. 2006. Introduction à la spectroscopie infrarouge. Pages 31-75 in La spectroscopie infrarouge et ses applications analytiques. 2nd ed. D. Bertrand and E. Dufour, ed. Editions TEC \& DOC, Paris, France. 
Lainé, A., A. Goubau, L.-M. Dale, H. B. Mabrouk, H. Hammami, and N. Gengler. 2013. Potential use of mid-infrared milk spectrum in pregnancy diagnosis of dairy cows. Page 523 in Proc. EAAP 64th Annual Meeting, Nantes, France. EAAP, Rome, Italy.

Lainé, A., H. B. Mabrouk, L.-M. Dale, C. Bastin, and N. Gengler. 2015. 7.2. Assessing the pregnancy status of dairy cows by midinfrared analysis of milk. Pages 273-278 in Precision Livestock Farming Applications. I. Halachmi, ed. Wageningen Academic Publishers, Wageningen, the Netherlands.

Mayeres, P., J. Stoll, J. Bormann, R. Reents, and N. Gengler. 2004. Prediction of daily milk, fat, and protein production by a random regression test-day model. J. Dairy Sci. 87:1925-1933.

McParland, S., G. Banos, E. Wall, M. P. Coffey, H. Soyeurt, R. F. Veerkamp, and D. P. Berry. 2011. The use of mid-infrared spectrometry to predict body energy status of Holstein cows. J. Dairy Sci. 94:3651-3661. http://dx.doi.org/10.3168/jds.2010-3965.

McParland, S., E. Lewis, E. Kennedy, S. G. Moore, B. McCarthy, M. O'Donovan, S. T. Butler, J. E. Pryce, and D. P. Berry. 2014. Mid-infrared spectrometry of milk as a predictor of energy intake and efficiency in lactating dairy cows. J. Dairy Sci. 97:5863-5871. http://dx.doi.org/10.3168/jds.2014-8214.

Meurens, M. 2006. Acuisition et traitement du signal spectrophotométrique. Pages 31-75 in La spectroscopie infrarouge et ses applications analytiques. 2nd ed. D. Bertrand and E. Dufour, ed. Editions TEC \& DOC, Paris, France.

Mohammed, R., S. M. McGinn, and K. A. Beauchemin. 2011. Prediction of enteric methane output from milk fatty acid concentrations and rumen fermentation parameters in dairy cows fed sunflower, flax, or canola seeds. J. Dairy Sci. 94:6057-6068. http://dx.doi. org/10.3168/jds.2011-4369.

Montoya, J. C., A. M. Bhagwat, N. Peiren, S. De Campeneere, B. De Baets, and V. Fievez. 2011. Relationships between odd- and branched-chain fatty acid profiles in milk and calculated enteric methane proportion for lactating dairy cattle. Anim. Feed Sci. Technol. 166-167:596-602. http://dx.doi.org/10.1016/j. anifeedsci.2011.04.080.

Mulligan, F. J., L. O'Grady, D. A. Rice, and M. L. Doherty. 2006. A herd health approach to dairy cow nutrition and production diseases of the transition cow. Anim. Reprod. Sci. 96:331-353. http:// dx.doi.org/10.1016/j.anireprosci.2006.08.011.

National Institutes of Health. 2001. Biomarkers and surrogate endpoints: Preferred definitions and conceptual framework. Clin. Pharmacol. Ther. 69:89-95. 10.1067/mcp.2001.113989.

Olesen, I., B. Gjerde, and A. F. Groen. 1999. Methodology for deriving non-market trait values in animal breeding goals for sustainable production systems. Interbull Bull. 23:13-21.

Plaizier, J. C., D. O. Krause, G. N. Gozho, and B. W. McBride. 2008. Subacute ruminal acidosis in dairy cows: The physiological causes, incidence and consequences. Vet. J. 176:21-31. http://dx.doi. org/10.1016/j.tvjl.2007.12.016.

Saeys, Y., I. Inza, and P. Larranaga. 2007. A review of feature selection techniques in bioinformatics. Bioinformatics 23:2507-2517. http://dx.doi.org/10.1093/bioinformatics/btm344.

Schukken, Y. H., D. J. Wilson, F. Welcome, L. Garrison-Tikofsky, and R. N. Gonzalez. 2003. Monitoring udder health and milk quality using somatic cell counts. Vet. Res. 34:579-596. http://dx.doi. org/10.1051/vetres:2003028.

Schwarz, D., D. M. Lefebvre, H. van den Bijgaart, J.-B. Davière, R. van der Linde, and S. Kold-Christensen. 2015. Global experience on ketosis screening by FTIR technology. Pages 5-10 in Proc. Technical Meeting of the International Committee for Animal Recording (ICAR), Krakow, Poland. ICAR technical series no. 19. ICAR, Rome, Italy.
Shenk, J. S., and M. O. Westerhaus. 1991. Population definition, sample selection, and calibration procedures for near infrared reflectance spectroscopy. Crop Sci. 31:469-474. http://dx.doi. org/10.2135/cropsci1991.0011183X003100020049x.

Soyeurt, H., F. G. Colinet, V. M.-R. Arnould, P. Dardenne, C. Bertozzi, R. Renaville, D. Portetelle, and N. Gengler. 2007. Genetic variability of lactoferrin content estimated by mid-infrared spectrometry in bovine milk. J. Dairy Sci. 90:4443-4450. http://dx.doi. org/10.3168/jds.2006-827.

Soyeurt, H., P. Dardenne, F. Dehareng, G. Lognay, D. Veselko, M. Marlier, C. Bertozzi, P. Mayeres, and N. Gengler. 2006. Estimating fatty acid content in cow milk using mid-infrared spectrometry. J. Dairy Sci. 89:3690-3695

Soyeurt, H., F. Dehareng, N. Gengler, S. McParland, E. Wall, D. P. Berry, M. Coffey, and P. Dardenne. 2011. Mid-infrared prediction of bovine milk fatty acids across multiple breeds, production systems, and countries. J. Dairy Sci. 94:1657-1667. http://dx.doi. org/10.3168/jds.2010-3408.

Soyeurt, H., I. Misztal, and N. Gengler. 2010. Genetic variability of milk components based on mid-infrared spectral data. J. Dairy Sci. 93:1722-1728. http://dx.doi.org/10.3168/jds.2009-2614.

Van Bebber, J., N. Reinsch, W. Junge, and E. Kalm. 1999. Monitoring daily milk yields with a recursive test day repeatability model (Kalman Filter). J. Dairy Sci. 82:2421-2429. http://dx.doi. org/10.3168/jds.S0022-0302(99)75493-7.

Van Haelst, Y. N. T., A. Beeckman, A. T. M. Van Knegsel, and V. Fievez. 2008. Short communication: Elevated concentrations of oleic acid and long-chain fatty acids in milk fat of multiparous subclinical ketotic cows. J. Dairy Sci. 91:4683-4686. http://dx.doi. org/10.3168/jds.2008-1375.

van Knegsel, A. T. M., H. van den Brand, J. Dijkstra, W. M. van Straalen, R. Jorritsma, S. Tamminga, and B. Kemp. 2007. Effect of glucogenic vs. lipogenic diets on energy balance, blood metabolites, and reproduction in primiparous and multiparous dairy cows in early lactation. J. Dairy Sci. 90:3397-3409. http://dx.doi. org $/ 10.3168 /$ jds.2006-837.

van Knegsel, A. T. M., S. G. A. van der Drift, M. Horneman, A. P. W. de Roos, B. Kemp, and E. A. M. Graat. 2010. Short communication: Ketone body concentration in milk determined by Fourier transform infrared spectroscopy: Value for the detection of hyperketonemia in dairy cows. J. Dairy Sci. 93:3065-3069. http:// dx.doi.org/10.3168/jds.2009-2847.

Vanlierde, A., M.-L. Vanrobays, F. Dehareng, E. Froidmont, H. Soyeurt, S. McParland, E. Lewis, M. H. Deighton, F. Grandl, M. Kreuzer, B. Gredler, P. Dardenne, and N. Gengler. 2015. Hot topic: Innovative lactation-stage-dependent prediction of methane emissions from milk mid-infrared spectra. J. Dairy Sci. http:// dx.doi.org/10.3168/jds.2014-8436.

Vanrobays, M.-L., J. Vandenplas, C. Bastin, H. Hammami, H. Soyeurt, A. Vanlierde, F. Dehareng, E. Froidmont, and N. Gengler. 2015. Genetic correlations between methane production and milk fatty acid contents of Walloon Holstein cattle throughout the lactation. In Final OptiMIR Scientific and Expert Meeting: From milk analysis to advisory tools (Palais des Congrès, Namur, Belgium, April 16-17, 2015). Biotechnol. Agron. Soc. Environ. 19:97-124.

Vigneau, E., Q. El Mostafa, B. Jaillais, G. Mazerolles, and D. Bertrand. 2006. Méthodes prédictives. Pages 347-401 in La spectroscopie infrarouge et ses applications analytiques. 2nd ed. D. Bertrand and E. Dufour, ed. Editions TEC \& DOC, Paris, France.

Vlaeminck, B., V. Fievez, S. Tamminga, R. J. Dewhurst, A. Van Vuuren, D. De Brabander, and D. Demeyer. 2006. Milk odd-and branched-chain fatty acids in relation to the rumen fermentation pattern. J. Dairy Sci. 89:3954-3964. 